\title{
VZTAH PREFEROVANÝCH VOLNOČASOVÝCH AKTIVIT A TVOŘIVOSTI U ČESKÝCH ADOLESCENTŮ
}

\author{
Jana Poddaná
}

\begin{abstract}
Abstrakt
Tématem studie je analýza vztahu volnočasových aktivit a tvořivosti u populace českých adolescentů ve věku 13-15 let. Pražští respondenti (N=398, žáci osmých tříd a studenti prvního ročníku šestiletého gymnázia) vyplnili dva testy tvořivosti. Prvním z nich je Torranceho test Neúplných figur, určený k měření neverbální tvořivosti, druhým je originální test Opice, který měří verbální tvořivost na základě respondenty vytvořeného krátkého tematického př́běhu. Výsledky verbálního i neverbálního testu tvořivosti byly vyhodnoceny ve vztahu $\mathrm{k}$ volnočasovým zájmům respondentů. Pomocí výpočtů explorační faktorové analýzy, analýzy variance (ANOVA) a Pearsonovým korelačním koeficientem byl zjištěn vztah mezi tvořivými volnočasovými aktivitami a figurálními i verbálními faktorovými skóry tvořivosti $(\mathrm{r}=0.149$ a $\mathrm{r}=0.161 ; \mathrm{p}<0.01)$. Mezi sociálními volnočasovými aktivitami a verbálním faktorovým skórem tvořivosti u gymnazistů byl nalezen pozitivní vztah $(\mathrm{r}=0.143)$. Nalezen byl také negativní vztah mezi pasivními volnočasovými zájmy a faktorem verbální tvořivosti $(\mathrm{r}=-0.101 ; \mathrm{p}<0.05)$. Následně bylo zjištěno, že typ navštěvované školy vysvětluje téměř $12 \%$ variance výkonu v neverbálním testu tvořivosti a pohlaví $2 \%$. Studenti gymnázií dosahovali signifikantně v obou testech tvořivosti vyšších výsledků než žáci základních škol, dívky dosahovaly signifikantně vy̌šśích výsledků než chlapci.
\end{abstract}

Klíčová slova: tvořivost, volnočasové aktivity, adolescence, testy tvořivosti

\section{RELATIONSHIP BETWEEN PREFERRED LEISURE TIME ACTIVITIES AND CREATIVITY OF CZECH TEENAGERS}

\begin{abstract}
The theme of the study is to analyze the relationship between leisure activities and creativity in the population of Czech adolescents aged 13-15 years. Prague respondents $(N=398$, eighth grade pupils and first-year students of a six-year grammar school) completed two tests of creativity. The first one former was the Torrance Test of Incomplete Figures examining nonverbal creativity, the latter was the original Monkey test examining verbal creativity by writing a short story about a picture. The results of the verbal and nonverbal test of creativity were confronted with the leisure time activities of the respondents. In the case of creative activities and creativity tests, a relation was found by explorative factor analysis, analysis of variance (ANOVA), and Pearson's correlation coefficient. Furthermore, a positive relation was found between creative leisure time activities and the nonverbal factor and even in the case of verbal factor of creativity $(r=0.149$ and $r=0.161 ; p<0.01)$. A positive relation was found between social leisure time activities and verbal factor of creativity among students of grammar school $(r=0.143)$. A negative relation was also found between passive leisure time activities and verbal factor of creativity $(r=-0.101 ; p<0.05)$. The type of school explained almost $12 \%$ variance of measured creativity in the Torrance Test, gender explained $2 \%$. Students of grammar schools scored in both creativity tests significantly higher than primary school pupils. Further, gender differences were found in both creativity tests while girls scored significantly higher than boys.
\end{abstract}

Key words: creativity, leisure activities, adolescence, creativity tests

Došlo: 8. 8. 2019

Schváleno: 14.8 .2020 
Fenomén tvořivosti se dnes stává velkým tématem z mnoha důvodů: společnost se mění, jedinec má více osobní svobody a volného času než kdy dříve, osobní tvořivost se prolíná s tvořivostí prospěšnou pro společnost. Pracovní svět si žádá inovativní pracovníky na nově se tvořící pozice. Je potřeba vychovávat děti i adolescenty tak, aby uměli být tvořiví: Henneseyová (2018) uvádí, že pro 65 \% žáků, kteří aktuálně vstupují do vzdělávacího procesu, jejich budoucí profese ještě ani neexistuje. Podle Csikszentmihalyiho (1996) patří vytváření jakýchkoliv tvořivých produktů (creative flow) mezi možnosti, jak dosáhnout osobního štěstí.

Co je to tvořivost? Na tuto otázku se snaží odborníci v oblasti psychologie odpovědět několik desetiletí. Ve výzkumech je tvořivost operacionalizována podle určitých výzkumných konceptů, př́padně není definována vůbec (Beghetto, 2018). Neexistuje jednotná, obecně přijímaná koncepce, $v$ níž by tvořivost byla nastíněna tak, aby tato schopnost mohla být vhodně a celistvě vysvětlena $v$ dalších oborech. Szobiová (2016) uvádí přehled definic podle jednotlivých autorských vymezení, které dělí do osmi kategorií. ${ }^{1}$ Nejednotnost definování tvořivosti se odráží i v praktické aplikaci, např́iklad ve školství. Chybějící konsensus podle Lucase (2016) komplikuje metodické zpracování rozvoje tvořivosti v rámci vzdělávacích programů. Odborná veřejnost se nicméně shoduje na tom, že tvořivý výsledek musí být nový (originální) a užitečný (adaptabilní) (Feist, 2010). Beghetto a Dow (in Beghetto, 2018) vytvořili na základě komparační analýzy definic tvořivosti její zobecnitelnou variantu:

„Tvořivost je interakce mezi nadáním, procesem a prostředím, která vytvář́ individuální nebo skupinové produkty, které jsou obecně vnímané jako nové a užitečné pro konkrétni sociální kontext.“ (s. 34)

Guilford a Torrance, jedni z prvních vědců na poli tvořivosti, zařazují tvořivost mezi myšlenkové procesy. Amabileová započala v 70. letech zkoumání sociální tvořivosti a na základě experimentů s pracovními kolektivy a ze získaných výsledků vyvodila komponentní model tvořivosti. Zmiňuje tři osobnostní komponenty (dovednost $\mathrm{v}$ daném oboru, tvořivě podpůrný proces a motivaci) a jednu komponentu nacházející se mimo osobnost: fungování organizace. Překvapivě zjistila, že nejenom vnitřní motivace, ale i vnější motivace má svůj dopad na tvořivost (Amabile, 2018). V roce 1993 vychází Gardnerova kniha Multiple inteligences: The theory in practice (česky Gardner, 1999), která ovlivnila i pohled na tvořivost. Stejně jako je nalezen obecný faktor u inteligence $g$, je také hledána centrální tvořivost. Ve své práci na tuto tezi volně navazují Baer a Kaufman (2005), kteří vyslovují názor, že tvořivost je soubor domén, které se navzájem nepodmiňují, ale koexistují vedle sebe, přičemž by mohla existovat jedna centrální tvořivost, která je sycena z jednotlivých domén. Sternbergova a Lubartova (1991) investiční teorie tvořivosti (stavící na strategii „levně koupit, draze prodat“) patří do ekonomických teorií tvořivosti a opírá se o kognitivní psychologii. Sám Sternberg (1988) chápe tvořivost jako jednu ze tř́i složek inteligence (spolu s analytickou a praktickou

\footnotetext{
${ }^{1}$ Tvořivost jako systém intelektových operací, tvořivost jako schopnost, tvořivost definovaná jako znak osobnosti, podstata tvořivosti je v motivaci, definice tvořivosti vycházející z tvořivého procesu a produktu, tvořivost jako výsledek interakce vnitřních a vnějších okolností, tvořivost je typ chování, tvořivost jako schopnost řešit problémy (Szobiová, 2016, s. 20-25).
} 
složkou). Obecně užívaná teorie tvořivosti „malé-c“ (každodenní tvořivost) a „Velké-C“ (produkty, které mají významné dopady na společnost) byla rozpracována Beghettem a Kaufmanem (2007; 2009) jako model čtyř C, v němž se ke stávajícím dvěma přidávají ještě „mini-c“, tedy tvořivost, která je potřebná ve vzdělávacím procesu, a „Pro-C“ tvořivost, která zastupuje profesionální (pracovní) stupeň tvořivosti.

Tvořivou osobností se celoživotně zabývá např́iklad Feist. Vytvořil model kreativní osobnosti, ve které nezapomíná na geneticko-epigenetické vlivy, z nichž vyplývají charakteristiky mozku, kognitivní, sociální, motivačně-afektivní a klinické rysy osobnosti. Na kreativní myšlení a chování má každá ze složek vliv (Feist, 2010). K nejčastějším rysům nadaných jedinců bývají přiřazovány tyto kategorie: tolerance vůči dvojznačnosti, stimulační svoboda, funkční svoboda, flexibilita, ochota riskovat, preference zmatku, prodleva uspokojení, oproštění se od stereotypu genderové role, vytrvalost a odvaha (více Dacey, Lennon, 2000; Zvěřinová, Janošová, 2012).

Př́stupy k tvořivosti v České republice a na Slovensku vycházejí z tradice 70 . let 20. století, kdy Hlavsa a Jurčová (1978) publikovali monografii Psychologické metódy zistovania tvorivosti, ve které se zabývají především identifikací tvořivých schopností a jejich rozvojem. Pod záštitou Jurčové vzniklo později na Slovensku mnoho projektů na podporu tvořivosti, a to převážně v oblasti př́rodovědných předmětů. Hlavsa (1981) chápe kreativitu jako projev kreativizace, což je možno chápat jako integritu tvořivé činnosti, života, subjektu a prostředí, vnitřních i vnějších stimulů. Na tento Hlavsův konstrukt navazuje Zelina, který rozšiřuje jeho tezi, a pod pojmem kreativizace chápe proces formování tvořivého stylu života (Zelina, Jaššová, 1984). V posledních dvou desetiletích se výzkumem tvořivosti na Slovensku zabývá především Szobiová, jejíž témata jsou hlavně problémy aplikace tvořivosti ve vzdělávání a výchově. V České republice vycházejí spíše monografie zaměřené na praktickou stránku rozvoje tvořivosti: Petrová, Tvořivost v teorii a praxi (1999), Königová, Jak myslet kreativně (2006), Žák, Kreativita a její rozvoj (2004). Chalupa se v knize Tvořivé myšlení (2005) zaměřuje především na kognitivní myšlení a řešení problémů.

Zkoumání tvořivosti u dětí a adolescentů není ve vědeckém světě nové. Významným vědcem zkoumajícím tvořivost u dětí je Torrance. V roce 1966 publikoval testy tvořivého myšlení (Torrance Tests of Creative Thinking - TTCT), které vycházejí ze dvou základních předpokladů. Prvním předpokladem je, že tvořivost je schopnost divergentního myšlení ${ }^{2}$ a druhým předpokladem, že tvořivost je jeden z myšlenkových procesů. Sám svoje testy čtyřikrát upravil (naposledy roce 1988). V původní verzi zkoumal Torrance originalitu (jedinečnost odpovědí), flexibilitu (rozmanitost odpovědí), fluenci (počet uznatelných odpovědí) a elaboraci (vypracování). V poslední verzi TTCT je opouštěna kategorie flexibilita, která při testování opakovaně vysoce korelovala s kategorií fluence (Cramond et al., 2005) a přidávají se dvě nové kategorie: odolnost vi̊či uzavření (schopnost zůstat otevřený a tolerantní k nejednoznačnosti, vychází z gestalt psychologie) a abstrakčnost názvu. Dále Torrance nalézá tato uvedená kritéria

\footnotetext{
${ }^{2}$ Teorie divergentního a konvergentního myšlení je z pera Guilforda, zakladatele moderního pohledu na tvořivost (v roce 1950 vystoupil na psychologické konferenci a požadoval zkoumání tvořivosti). Divergentní myšlení je proces, při kterém se generují originální myšlenky, jež mohou být rozbíhavé, nesměřující $\mathrm{k}$ jasnému závěru a jsou otevřené. Toto myšlení se používá ve chvílích, kdy $\mathrm{k}$ cíli vede mnoho cest (např. malba obrazu). Opakem je myšlení konvergentní, sbíhavé. Toto myšlení využívá logických postupů a vede $\mathrm{k}$ jednomu jasnému cíli (napřr. $2+2=4$ ).
} 
pro výzkum tvořivosti: emocionálni expresivita, vnitřni vizualizace, vyprávění, rozšiřování nebo lámáni hranic, pohyb ve smyslu akce, humor, expresivita názvů, obrazotvornost, syntéza neúplných čisel, pestrost obrazů, syntéza čar nebo kruhü, fantazie a neobvyklá vizualizace. Torranceho testy byly a jsou předmětem mnoha zkoumání (Torrance, 1991; Cramond et al., 2005; Cropley, 2018 aj.) i kritiky (Kim, 2006; Almeida et al., 2008; Runco et al., 2010; Runco, 2014; aj.).

Jedním z velkých výzkumných oborů je tvořivost a vzdělávání. Odborníci se shodují, že klasické vzdělávání tvořivost nepodporuje (Runco, 2014; Beghetto, 2018, aj.). Učitelé preferují žáky dochvilné, přesné, takové, kteří plní zadání bez otázek. Tvořivost je ale spojována s autonomií, nekonvenčností a nonkonformitou (Torrance, 1972, in Runco, 2014). V posledních desetiletích se pojem tvořivost dostává do národních kurikulí ${ }^{3}$ a počet publikací na toto téma vzrůstá. Např́iklad Beghetto (2018) se dlouhodobě snaží o spojení tvořivosti a výuky. Vytváří koncepci, ve které je nutné učit učitele, jak být tvořiví: „učení pro tvořivost, tvořivě a o tvořivosti“ (s. 42). Ve své jiné práci (Beghetto, 2014) také používá pojem „kreativní umrtvování“, které se vztahuje k učitelovu chování, které brání vývoji tvořivého potenciálu dětí a adolescentů (např. neadekvátní kritika žákovských produktů).

Konstrukt tvořivosti, z nějž vychází tato studie, se opírá o operacionalizaci tohoto pojmu podle Torranceho a je také inspirován poznatky týkajícími se jmenovaných rysů tvořivého jedince podle Daceyho a Lennonové (2000). Z našeho pohledu jde tedy o schopnost řešit úkoly originálně a vytvářet maximální počet variabilních prvků, které korespondují se zadáním úkolu. Zároveň je pro tento výkon stanoven určitý časový limit (více v naší předešlé práci: Zvěřinová, Janošová, 2012).

Volnočasové aktivity jsou v sociologickém kontextu chápany jako činnosti, které si jedinec volí včase mimo povinnou práci. Cílem těchto činností je uspokojit potřeby, odpočinout si, pobavit se. Tyto činnosti jsou většinou syceny vnitřní motivací a vyvolávají v nás radost. Dnešní děti mají daleko více volného času než předešlé generace, a navíc jsou zvyklé používat moderní technologie (Sak, Saková, 2004; Kirkorian et al., 2010; Bucksch et al., 2014; Šafr, Patočková, 2010; Sak, 2016). Důležitost výběru volnočasových aktivit u dětí i dospívajících je podstatná především ve vztahu k jejich budoucímu (nejenom pracovnímu) životu a jejich hodnotovému systému (Sak, Saková, 2004).

\footnotetext{
${ }^{3}$ Koncepce rozvoje potenciálu tvořivosti u žáků a studentů do svých kurikul zahrnuje nejeden stát, nejčastěji zmiňované je kurikulum Spojených států amerických, Austrálie nebo Skotska. Ve vzdělávacím kurikulu České republiky je rozvoj tvořivosti chápán takto: „MŠMT bude směřrovat ke vzdělávacímu systému, který stimuluje maximální rozvoj a plné využití potenciálu všech žáků včetně rozvoje jejich tvořivosti, a to již od předškolniho věku, přičemž tato podpora je dlouhodobá a systematická, zahrnuje oblasti formálního, zájmového i neformálního vzdělávání. " Dopad uvedených slov ale není v praxi známý. Lucas ve své studii (2016) sledoval reálný dopad zavedení pojmu tvořivost do anglického vzdělávacího kurikula. Přestože v Anglii (USA nebo Austálii) mají programy rozvoje tvořivosti, ani v těchto zemích není jasně definována kontrola plnění plánu. Dále Lucas uvádí: „Pokud neexistuje definice pojmu vhodná pro školství ani pro vývoj tvořivosti u dětí, tak nikdy nebudeme schopni tvořivost ve vzdělávacím procesu postihnout a kontrolovat.“(s. 279).
} 
Mezi klasické členění volnočasových aktivit patří dělení na aktivní a pasivní. Kraus a kol. (2001) dělí činnosti na tvůrčí, kulturní, sportovní (shodují se s aktivními, rozvíjejícími zájmy) a konzumni (pasivní, nerozvíjející zájmy). Odlišné třídění, pro nás ne zcela bez zajímavosti, nabízí Sak (2000). Rozlišuje zájmy podle zaměření na kulturně orientované (návštěva divadla, koncertů, četba knih, aj.), sportovně zaměrené (aktivní a pasivní sport, domácí práce, počítačové hry - srovnej níže), extrovertní (návštěva kaváren a restaurací, schůzky s partnerem, diskotéky), manuálni (chov zvířat, kutilství) a introvertně-konzumní (poslech hudby, nudění se, sledování televize). Podle obsahu se také dají zájmy dělit na společenskovědní, pracovnětechnické, př́rodovědně-ekologické, esteticko-výchovné, tělovýchovné, sportovní a turistické (Pávková a kol., 2008).

Náš pohled na volnočasové aktivity zahrnuje vztah k tvořivosti, což znamená, že zájmy jsou děleny právě podle toho, jestli je aktivita vynalézavá, inovativní a originální a také podle toho, jestli je při dané činnosti respondent duševně aktivní či ne. Je důležité zkoumat volnočasové aktivity u dětí a adolescentů a zjistit, jestli některé z aktivit mají tvořivostní potenciál, nebo jestli si tvořivé aktivity vybírají děti a adolescenti, kteří jsou vychovávání tvořivěji a v podnětnějším prostředí než jejich vrstevníci. Zatím je vědecké zkoumání volnočasových aktivit ve vztahu k tvořivosti okrajovou záležitostí: zkoumají se pouze vybrané aktivity, velice často stojící na okraji jiných zkoumaných jevů.

Wadeová (1971) zkoumala tvořivé jedince a výběr užívaných médií (televizní sledování, rádiový poslech, četba novin). Ve svém výzkumu 105 škol v okolí San Franciska vychází z Guilfordovy teorie divergentního myšlení a při testování používá právě jeho test a dotazník na výzkum informací vybraných médií. Výchozím výsledkem bylo zjištění pozitivního vztahu mezi naměřenými hodnotami mezi inteligenčním kvocientem a skóry z testu tvořivosti. Pokud jednou z proměnných byla hodnota IQ, nalezla mezi zkoumanými médii a testy tvořivosti pozitivní korelační vztahy, pokud ale tuto proměnnou vyřadila, tak např́iklad mezi četbou novin a skóry z testů tvořivosti nebyl nalezen žádný vztah. Mezi její další zjišsěné poznatky patří i to, že čím více mají respondenti bodů $\mathrm{v}$ testu tvořivosti, tím méně času stráví $\mathrm{s}$ médii a tím více různých zájmů mají. Tento fakt potvrzuje i aktuálnějšś studie Marequeové et al. (2019), v níž autoři shrnují, že $\mathrm{s}$ vyšším počtem aktivit stoupá i počet bodů $\mathrm{v}$ testech tvořivosti. Krummová et al. (2018) nalezli pozitivní vztahy mezi preferencí sociálních vztahů a skóry $\mathrm{v}$ testech tvořivosti. Negativní vztah mezi tvořivostí a sledováním televize u indických adolescentů našel Kant (2012).

V naší první studii (Zvěřinová, Janošová, 2012) jsme na vzorku 121 adolescentů zkoumaly vztah počtu hodin strávených hráním počítačových her a výsledky tvořivosti. V uvedené studii jsme vyšetřovaly tvořivost pomocí Torranceho testu Neúplných figur a vlastního testu Opice, jehož proměnné jsou detailně uvedeny právě ve zmíněné studii. Mezi zjištěné poznatky patří nalezení vztahu mezi počtem hodin hraní a skóry z testů tvořivosti: čím více času tráví respondenti hraním počítačových her, tím jsou jejich výsledky v testech tvořivosti nižší $(\mathrm{r}=-0.20, \mathrm{p}<0.05)$. Na populaci pražských adolescentů jsme také našli významný negativní vztah mezi typem her „bojové“ a neverbálním testem tvořivosti. Naproti tomu, Hamlenová (2009) vztah mezi videohrami a tvořivostí (také zkoumanou TTCT) u americké populace školních dětí neprokázala. 
Cílem této studie je přispět k poznání tvořivosti a zjistit, jestli existují vztahy mezi tvořivostí a volnočasovými zájmy u českých adolescentů. Předpoklad této studie je, že tvořivé aktivity mají pozitivní vztah se skóry z testů tvořivosti a sociální aktivity mají pozitivní vztah s výsledky z verbálního testu. Domníváme se, že pasivní aktivity mají záporný vztah s výsledky z testů tvořivosti. Sledujeme také, zda existuje vztah mezi výsledky z testi̊ tvořivosti, genderem a typem školy.

\section{Výzkumný soubor}

Osloveni byli pražští studenti prim šestiletého gymnázia a žáci osmých tříd základních škol ve věku 13-15 let. Před sběrem dat byly získány informované souhlasy s účastí ve výzkumu od 98 \% rodičů těchto žáků a studentů. Odmítnutí participace ze strany žáků a studentů na místě se nevyskytlo. Soubor respondentů, kteří se výzkumu zúčastnili, tvořilo 398 žáků a studentů (214 dívek a 184 chlapců; 112 středoškolských studentů a 286 žáků základních škol). Sběr dat se uskutečnil v červnu a záŕí 2013 a probíhal vždy jednu vyučovací hodinu v každé školní třídě bez př́tomnosti pedagogů.

\section{Výzkumné nástroje}

Tvořivostní test I. sestával z upravené verze Torranceho testu Neúplných figur (volně použito z Jurčové, 1984 a doplněno o nové poznatky). Tento test je zaměřený na neverbální, figurální stránku tvořivosti. Na výtvarné dotvoření deseti různých neúplných obrazců a jejich pojmenování měli probandi osm minut. U výsledků testu byly následně hodnoceny tyto kategorie (srov. Dacey, Lennon, 2000): 1) fluence, 2) originalita, 3) elaborace (vypracování) a 4) název. U Torranceho neverbálního testu tvořivost jsou často nalezeny dva faktory sycení (Cramond et al., 2005; Almeida et al., 2008). V našem případě po provedení explorační faktorové analýzy byl nalezen pouze jeden faktor (faktory zátěže: fluence $=0,759$; originalita $=0,749$; vypracování $=0,491$; název $=0,789)$. Vnitřní konsistence (Cronbachova $\alpha$ ) pro výše uvedené čtyři sledované kategorie testu Neúplných figur byla 0,65 .

Tvořivostní test II. byl prezentován vlastním testem verbálni tvořivosti s názvem Opice. Úkolem respondentů bylo vymyslet a napsat co nejvíce originální a nápaditý př́běh motivovaný vyobrazením opice s batohem na zádech a s čelovkou ${ }^{4}$ (Zvěřinová, Janošová, 2012). Sledovaná kritéria odpovídala kategoriím tvořivé osobnosti popsaným autory Dacey a Lennonová (2000). Jednalo se o: 1) celistvost myšlenky, 2) slovní vypracování, 3) slovní pružnost a 4) stimulační svobodu a 5) název. Na sepsání prŕiběhu a vymyšlení jeho názvu měli respondenti osm minut, stejně jako u neverbálního testu. Pomocí faktorové analýzy byl nalezen jeden společný faktor pro zkoumané proměnné (faktory zátěže: celistvost myšlenky $=0,422$; slovní vypracování $=$ 0,429 ; slovní pružnost $=0,630$; stimulační svoboda $=0,657$; název $=0,283$ ). Hodnota Cronbachovy $\alpha$ pro výše uvedené sledované kategorie testu Opice byla 0,72 . Interkorelační signifikantně významný vztah mezi oběma testy byl r=0,41.

\footnotetext{
${ }^{4}$ Tento typ testů použili ve svých studiích např́klad Ripple a Dacey (1967).
} 
Probandi dostali arch s rozvrhem, do něhož uváděli, jakým činnostem se věnovali během stanoveného jednoho pracovního a jednoho víkendového dne z posledního týdne. Tyto aktivity vyplňovali do připraveného formuláře, strukturovaného po třicetiminutových časových úsecích.

Zaznamenané činnosti byly následně rozděleny na činnosti nutné (např.: spánek, škola, aj.), zájmy aktivní (konání, při němž jsou probandi činorodí, ne však tvořiví, nevytvářejí při této činnosti nic originálního ani užitečného), pasivní záliby (při nichž je jedinec nečinným, pasivním přijímatelem zábavy nebo informací), sociální zájmy (jejichž podstatou je komunikace s druhými lidmi) a aktivity tvořivé (činnosti, při nichž jedinec vytváří něco originálního, vynalézavého a inovativního).

\section{Výsledky}

Ke statistické analýze dat jsme použili statistický program IBM Statistisc SPSS 20. Explorační faktorovou analýzou jsme zjišt'ovali počet faktorů u jednotlivých tvořivostních testů. K posouzení reliability (vnitřní konzistence) testů jsme využili Crombachův koeficient alfa. U jednotlivých skupin jsme zjišt'ovali průměr, maxima a minima, směrodatnou odchylku a průměr. Výsledky byly analyzovány pomocí výpočtu analýzy variance (ANOVA) a s pomocí Pearsonova korelačního koeficientu jsme dále ověřili vzájemnou korelaci mezi faktorovými skóry a proměnnými.

\section{Zájmy a jejich rozdělení do kategorií}

Informace získané z rozvrhu byly nejprve rozděleny na činnosti nutné a na zájmy. Mezi nutné činnosti byla zařazena školní docházka (necelých 6 hodin denně během pracovního týdne), domácí práce, brigády, péče o sourozence, péče o zahradu, čekání, příprava, cestování, hygiena a jídlo (celkem průměrně 3 hodiny denně). Respondenti v uvedené studii spali 8 hodin během pracovního týdne a 10 hodin během víkendu. Činnosti nutné nebyly ve výzkumu dále blíže sledovány, protože neodpovídají definici volnočasových aktivit. Na vlastní zájmy zbývá průměrnému respondentovi 8 hodin denně během pracovního dne a okolo 10 hodin během víkendového dne.

Jak již bylo uvedeno, jednotlivé zájmy byly následně rozděleny do čtyř základních kategorií $\mathrm{z}$ pohledu vztahu $\mathrm{k}$ tvořivosti (průměrné počty minut strávených danou aktivitou během jednoho školního dne a jednoho víkendového dne jsou uvedeny v tabulce 1). Mezi pasivní volnočasové zájmy byly začleněny následující konkrétní činnosti: odpočinek, používání mobilu nebo počítače bez konkrétního cíle, poslech hudby, sledování televize, filmů, seriálů, sportovních utkání a hraní počítačových her. Pasivní zájmy pravděpodobně nebudou posilovat tvořivý potenciál a je možné, že tento typ zájmů bude vykazovat záporný korelační vztah s výsledky z testů tvořivosti.

Mezi zájmy aktivní byly začleněny následující činnosti: chov zviŕat, kulturní vyžití, jako je návštěva kina, knihovny, muzea či výstavy, sport, rybaření, řízení motorového vozidla (závodění), náboženské aktivity. Předpokládáme, že aktivní zájmy nebudou mít s tvořivostí vztah. Tyto aktivity mohou být tvořivé, ale také nemusejí. 
Tabulka 1: Průměrná denní doba (včetně víkendů) strávená sledovanými typy volnočasových aktivit (počty minut a směrodatné odchylky)

\begin{tabular}{|c|c|c|c|c|c|c|c|c|c|c|}
\hline \multirow{2}{*}{ typ aktivity } & \multicolumn{2}{|c|}{ celkem } & \multicolumn{2}{|c|}{ dívky } & \multicolumn{2}{|c|}{ chlapci } & \multicolumn{2}{|c|}{ ZŠ } & \multicolumn{2}{|c|}{$\mathrm{SŠ}$} \\
\hline & minuty & SD & minuty & SD & minuty & SD & minuty & SD & minuty & SD \\
\hline pasivní & 240 & 11,7 & 173 & 8,1 & 318 & 12,8 & 246 & 12,5 & 204 & 8,3 \\
\hline aktivní & 156 & 8,1 & 177 & 8,3 & 131 & 7,5 & 168 & 8,8 & 130 & 5,7 \\
\hline sociální & 68 & 6 & 80 & 6,1 & 54 & 5,7 & 74 & 6,5 & 53 & 4,2 \\
\hline tvořivé & 71 & 5,2 & 80 & 5,0 & 61 & 5,3 & 53 & 4,4 & 118 & 5,8 \\
\hline $\begin{array}{l}\text { průměrná denní doba } \\
\text { strávená aktivitami (jeden } \\
\text { pracovní den, jeden } \\
\text { víkendový den) }\end{array}$ & \multicolumn{2}{|c|}{$\begin{array}{c}8 \text { hodin } 57 \\
\text { minut }\end{array}$} & \multicolumn{2}{|c|}{$\begin{array}{c}8 \text { hodin } 30 \\
\text { minut }\end{array}$} & \multicolumn{2}{|c|}{$\begin{array}{c}9 \text { hodin } 24 \\
\text { minut }\end{array}$} & \multicolumn{2}{|c|}{9 hodin } & \multicolumn{2}{|c|}{$\begin{array}{c}8 \text { hodin } 24 \\
\text { minut }\end{array}$} \\
\hline
\end{tabular}

K sociálním zájmům byly přiřazeny aktivity, jako je návštěva diskotéky, hraní společenských her, komunikace včetně komunikace po internetové síti (Facebook, Instagram, Skype a podobné), návštěva rodiny či kamarádů, oslava, randění. Sociální aktivity by mohly mít pozitivní vztah s verbálními testy tvořivostí.

Mezi aktivity tvořivé byly zařazeny aktivity manuálně tvořivé jako oprava auta, tvorba z korálků, modelářství, dále výtvarné činnosti, fotografování a úprava fotografií, tvorba webových stránek, módní návrhářství a tvorba účesů, hra na hudební nástroj, programování, psaní deníků a příběhů, blogování, hraní si se sourozencem, čtení knih ${ }^{5}$ a vypracovávání úkolů spojených se školní výukou (je zjevné, že domácí úkoly by asi sami respondenti zařadili do činností nutných, my však předpokládáme, že úkoly jsou specifickou součástí volného času, protože je na respondentovi, kolik času u nich opravdu stráví, popřípadě, jestli vůbec u nich čas tráví).

U všech zmiňovaných aktivit jsme si vědomi toho, že je lze provozovat s větší nebo menší mírou tvořivosti. Součástí této studie není zjištování podílu organizovaného volného času oproti zcela neorganizovanému volnému času dospívajících.

\section{Tvořivost ve sledovaných podsouborech}

Prezentaci základních popisných statistických údajů (průměry a směrodatné odchylky výsledků) u obou testů tvořivosti nalezneme v tabulce č. 2.

\footnotetext{
${ }^{5}$ Při četbě knih je potřeba fantazie a imaginace, tyto obě schopnosti vykazují pozitivní korelační vztahy s tvořivostí (Runco, 2014).
} 
Tabulka 2: Popisné údaje výsledků dosažených v neverbálním testu Neúplných figur a verbálním testu Opice

\begin{tabular}{|c||c||c|c|c|c|c|c|c|c|}
\hline \multicolumn{1}{|c||}{} & \multicolumn{1}{c||}{} & \multicolumn{3}{c|}{ verbální test Neúplných figur } & \multicolumn{5}{c|}{ neverbální test Opice } \\
\cline { 2 - 12 } & počet & min. & max. & průměr & SD & min. & max. & průměr & SD \\
\hline \multirow{2}{*}{ dívky } & 214 & 4 & 32 & 20,8 & 4,7 & 3 & 36 & 20,3 & 6,5 \\
\hline chlapci & 184 & 3 & 31 & 19,6 & 4,6 & 0 & 31 & 18,2 & 6,6 \\
\hline ZŠ & 286 & 3 & 31 & 19,3 & 4,5 & 0 & 36 & 18,6 & 6,5 \\
\hline SŠ & 112 & 12 & 32 & 22,6 & 4,3 & 0 & 35 & 21,3 & 6,2 \\
\hline celkem & 398 & 3 & 32 & 20,7 & 4,7 & 0 & 36 & 19,3 & 6,5 \\
\hline
\end{tabular}

Poznámka: ** $\mathrm{p}<0.01, * \mathrm{p}<0.05$, platí i pro další tabulky

Verbální i neverbální tvořivost jsme zkoumali v závislosti na dvou proměnných. První proměnnou je pohlaví a druhou typ navštěvované školy. Pomocí analýzy variance (ANOVA) jsme zjistili, že v základním souboru lze očekávat rozdíly mezi jednotlivými průměry (viz tabulka 3). Ve všech př́ípadech byly zjištěny signifikace na úrovni $p<0.01$. Dívky dosahují vyšších skórů $v$ testech tvořivosti než chlapci. Studenti gymnázií mají průměrně vyšší skóry z testů tvořivosti než stejně staří žáci základních škol. Velikost účinku typu školy na neverbální test je $12 \%$, na verbální test $4 \%$. Velikost účinku pohlaví na neverbální test je $2 \%$ a na verbální test $3 \%$.

Tabulka 3: Rozdíly mezi skupinami ve skórech testů tvořivosti zjištěné mezi pomocí analýzy variance (ANOVA) u typu školy a pohlaví

\begin{tabular}{|c|c|c|c|c|c|c|c|}
\hline \multicolumn{2}{|c|}{ typ školy } & SČ & df & průměr & $\mathrm{F}$ & $\mathrm{r}^{2}$ & sig. \\
\hline $\begin{array}{l}\text { test Neúplné } \\
\text { figury }\end{array}$ & $\begin{array}{l}\text { mezi skupinami } \\
\text { uvnitř skupin } \\
\text { total }\end{array}$ & $\begin{array}{l}1044,152 \\
7694,081 \\
8738,234 \\
\end{array}$ & $\begin{array}{r}1 \\
396 \\
397 \\
\end{array}$ & $\begin{array}{r}1044,152 \\
19,429\end{array}$ & 53,741 & 0,35 & 0,000 \\
\hline test Opice & $\begin{array}{l}\text { mezi skupinami } \\
\text { uvnitř skupin } \\
\text { total }\end{array}$ & $\begin{array}{r}602,116 \\
16165,766 \\
16767,882 \\
\end{array}$ & $\begin{array}{r}1 \\
396 \\
397 \\
\end{array}$ & $\begin{array}{r}602,116 \\
40,823\end{array}$ & 14,750 & 0,19 & 0,000 \\
\hline \multicolumn{8}{|c|}{ pohlaví } \\
\hline $\begin{array}{l}\text { test Neúplné } \\
\text { figury }\end{array}$ & $\begin{array}{l}\text { mezi skupinami } \\
\text { uvnitř skupin } \\
\text { total }\end{array}$ & $\begin{array}{r}154,083 \\
8584,150 \\
8738,234 \\
\end{array}$ & $\begin{array}{r}1 \\
396 \\
397 \\
\end{array}$ & $\begin{array}{r}154,083 \\
21,677\end{array}$ & 7,108 & 0,13 & 0,008 \\
\hline test Opice & $\begin{array}{l}\text { mezi skupinami } \\
\text { uvnitř skupin } \\
\text { total }\end{array}$ & $\begin{array}{r}461,002 \\
16306,880 \\
16767,882 \\
\end{array}$ & $\begin{array}{r}1 \\
396 \\
397 \\
\end{array}$ & $\begin{array}{r}461,002 \\
41,179\end{array}$ & 11,195 & 0,17 & 0,001 \\
\hline
\end{tabular}




\section{Vztah mezi tvořivostí a volnočasovými aktivitami}

Pomocí korelace (výpočet Pearsonova korelačního koeficientu) byl zjišt'ován vztah mezi faktorovými skóry jednotlivých testů tvořivosti a typy volnočasových aktivit (tabulka 4). Faktor získaný z Torranceho testu Neúplných figur jsme nazvali faktor figurální tvořivosti a faktor nalezený z výsledků verbálního testu Opice jsme nazvali faktor verbální tvořivosti. V př́padě faktoru figurální tvořivosti byl zaznamenán slabý signifikantní vztah $\mathrm{s}$ tvořivými volnočasovými zájmy respondentů $(\mathrm{r}=0.149 ; \mathrm{p}<0.01)$. U faktoru verbální tvořivosti byl také nalezen signifikantní vztah $\mathrm{s}$ tvořivými zájmy $(\mathrm{r}=0.161 ; \mathrm{p}<0.01)$ a slabý negativní vztah s pasivními zájmy $(\mathrm{r}=-0.101 ; \mathrm{p}<0.05)$.

Tabulka 4: Vztah mezi faktorovými skóry tvořivosti a typy volnočasových aktivit u dívek a chlapců a žáků ZŠ a studentů SŠ (Pearsonův korelační koeficient)

\begin{tabular}{|c|c|c|c|c|c|c|c|c|c|c|}
\hline \multirow{2}{*}{$\begin{array}{c}\text { typ } \\
\text { aktivity }\end{array}$} & \multicolumn{2}{|c|}{ všichni } & \multicolumn{2}{|c|}{ chlapci } & \multicolumn{2}{|c|}{ dívky } & \multicolumn{2}{|c|}{$\mathbf{Z S}$} & \multicolumn{2}{|c|}{$\mathbf{S S}$} \\
\hline & $\begin{array}{c}\text { faktor } \\
\text { figurální } \\
\text { tvořivosti }\end{array}$ & $\begin{array}{c}\text { faktor } \\
\text { verbální } \\
\text { tvořivosti }\end{array}$ & $\begin{array}{c}\text { faktor } \\
\text { figurální } \\
\text { tvořivosti }\end{array}$ & $\begin{array}{c}\text { faktor } \\
\text { verbální } \\
\text { tvořivosti }\end{array}$ & $\begin{array}{c}\text { faktor } \\
\text { figurální } \\
\text { tvořivosti }\end{array}$ & $\begin{array}{c}\text { faktor } \\
\text { verbální } \\
\text { tvořivosti }\end{array}$ & $\begin{array}{c}\text { faktor } \\
\text { figurální } \\
\text { tvořivosti }\end{array}$ & $\begin{array}{c}\text { faktor } \\
\text { verbální } \\
\text { tvořivosti }\end{array}$ & $\begin{array}{c}\text { faktor } \\
\text { figurální } \\
\text { tvořivosti }\end{array}$ & $\begin{array}{c}\text { faktor } \\
\text { verbální } \\
\text { tvořivosti }\end{array}$ \\
\hline pasivní & -.097 & $-.101 *$ & -.043 & -.009 & -.038 & -.073 & -.053 & -.069 & -.084 & -.104 \\
\hline aktivní & -.057 & -.052 & -.022 & -.028 & $-.137 *$ & -.131 & -.001 & -.016 & -.069 & -.051 \\
\hline sociální & .021 & .048 & .025 & .120 & -.020 & -.050 & .082 & .058 & -.035 & .143 \\
\hline tvořivé & $.149 * *$ & $.161 * *$ & .075 & .027 & $.187 * *$ & $.247 * *$ & .011 & .080 & .066 & .100 \\
\hline
\end{tabular}

Ve sledovaných podsouborech bylo zjištěno několik signifikantních interkorelačních vztahů. Byl nalezen významný vztah mezi tvořivými aktivitami a faktorem verbálním i figurálním $\mathrm{u}$ dívek ( $\mathrm{r}=0.247$ a $\mathrm{r}=187 ; \mathrm{p}<0.01)$. U chlapců se však tyto vztahy neprojevovaly. U dívek byl zaznamenán také slabý negativní vztah, který se týkal aktivních zájmů a výkonů v obou testech tvořivosti $(\mathrm{r}=-0.137 ; \mathrm{p}<0.05)$. Také byl nalezen slabý významný vztah mezi tvořivými aktivitami a faktorem verbální tvořivosti u studentů gymnázií, ( $\mathrm{r}=0.100)$, nebyl však shledán signifikantním. Stejně tak byl nalezen slabý vztah mezi sociálními aktivitami a faktorem verbální tvořivosti, nebyl však statisticky významný. U žáků základních škol nebyly mezi oběma faktory tvořivosti a volnočasovými aktivitami prokázány žádné významné vztahy, směry působení ale odpovídají ostatním zjištěným nálezům.

\section{Diskuse}

Povaha získaných dat v zásadě dovoluje ověřit předpoklad, že typ volnočasových aktivit souvisí $\mathrm{s}$ výsledky $\mathrm{v}$ testech tvořivosti. Ukazuje se tedy, že existuje vztah mezi způsobem trávení volného času a výkonem v tvořivosti. Čas strávený tvořivými volnočasovými aktivitami koreluje s faktory figurální i verbální tvořivosti. Mezi pasivními zájmy a faktory tvořivosti byly nalezeny slabé negativní vztahy, u celku statisticky významné. Existuje také vztah mezi sociálními zájmy a faktorem verbální tvořivosti. 
Žáci základních škol dosahují v testech tvořivosti nižších skórů než stejně staří studenti gymnázií $(\mathrm{p}<0.01)$. Typ školy vysvětluje v př́ípadě neverbálního testu $12 \%$ variance, $\mathrm{v}$ př́padě Opice $2 \%$. Dívky dosahují vyšších skórů v testech tvořivosti než chlapci $(p<0.01)$. Pohlaví vykazuje v př́ípadě neverbálního testu Neúplných figur $2 \%$ variance, $v$ př́ípadě verbálního testu Opice $3 \%$.

Podle studie Larsona (2001) tráví adolescenti v USA svými zájmy 6,5-8 hodin denně, adolescenti ve východní Asii tráví svými zájmy 4-5,5 hodiny denně a evropští adolescenti tráví svými zájmy 5,5-7,5 hodiny denně. Respondenti z naší studie tráví zájmy více než osm hodin denně, což převyšuje evropské výsledky uvedené studie. Dívky tráví svými zájmy skoro o hodinu denně méně času než chlapci. Respondenti z gymnázia tráví, zřejmě v důsledku náročnějšího studia, svými zájmy o více než půl hodinu denně méně času než jejich vrstevníci ze základních škol.

Pasivní zájmy, jako je odpočinek, používání mobilu nebo počítače bez konkrétního cíle, poslech hudby, sledování televize, filmů a hraní počítačových her, zaujímají skoro polovinu uvedeného času volnočasových aktivit zkoumaných jedinců. Tento fakt potvrzuje mnoho zahraničních i českých studií zabývajících se touto problematikou (např.: Larson, 2001; Vleioras, 2010; Sak, Saková 2004, Šafr a Patočková, 2010; Sak, 2016). Pasivní zájmy jsou v naší studii uvažovány jako činnosti, při nichž jedinec nevytváří nic originálního, není aktivní a prííímá informace, postoje a hodnoty ze zdrojů, které většinou vybírá bez hlubšího rozmyslu. $\mathrm{Z}$ této studie vyplývá, že pasivní zájmy negativně souvisí s výkonem v tvořivosti. Pasivními zájmy tráví čas ze zkoumaných skupin více chlapci (více než 5 a půl hodiny denně) a tento údaj pravděpodobně vysvětluje jejich celkově nižší výsledky v testech tvořivosti. Dívky pasivními zájmy tráví průměrně 4 hodiny denně, což se může také odrážet v jejich vyšších výkonech v testech tvořivosti. Ze zjištěného vyplývá, že pasivní aktivity sice „neumrtvuji“ tvořivost, ale také ji neposilují. Pro rozvoj tvořivého potenciálu jsou vhodnější jiné aktivity, včetně jejich rozmanitosti.

Nízká variabilita volnočasových aktivit, což platí hlavně u jedinců preferujících pasivní zájmy, také může souviset s nižšími výkony v tvořivosti (pokud např́íklad jedinec vykonává ve svém volném čase pouze jeden z pasivních zájmů, je nepravděpodobné, že by rozvíjel širší spektrum kognitivních schopností, tím méně tvořivost). Toto potvrzují i studie Wadeové (1971) či Marequeové a kol. (2019). Např́klad sledování televize (s výjimkou Sesame street, česky Sezame, otevři se) nemělo žádný příznivý vliv na kognitivní vývoj dětských diváků. Nejen u sledování televize, ale ani u poslechu rádia nebyl prokázán žádný vliv na tvořivost dětí (Runco, Pezdek, 1984; Kirkorian et al., 2008). U počítačových her a tvořivosti nejsou výzkumy jednotné, Hamlenová (2009) neprokázala vztah u americké adolescentní populace mezi hraním počítačových her a tvořivostí zkoumanou Torranceho testem tvořivosti, zatímco Zvěřinová a Janošová (2012) mezi počtem hodin hraní počítačových her a tvořivostí u české adolescentní populace negativní vztah nalezly.

Zájmy aktivní jako jsou chov zvířat, kulturní vyžití, sport, rybaření, řízení motorového vozidla a brigáda, jsou definovány jako činnosti, při nichž jsou probandi činorodí, ne však tvořiví, nevytvářejí při této činnosti nic inovativního. Těmito zájmy tráví zkoumaní adolescenti přibližně 2,5 hodiny denně, přičemž největší podíl z této skupiny aktivit zaujímá sport. Obecně se soudí, že chlapci jsou více zaměřeni na sportovní aktivity než dívky (Janošová, 2008), v naší 
studii tomu tak ale není. Dívky v naší studii se věnují aktivním zájmům o 45 minut denně více než chlapci. U dívek byl nalezen mezi aktivními zájmy a faktorem figurální tvořivostí slabý negativní signifikantní vztah.

Mezi zájmy sociální, jejichž podstatou je komunikace s druhými lidmi, patří návštěva diskotéky, hraní si se sourozencem, hraní společenských her, komunikace po internetové síti i mimo ni (včetně Facebooku a jiných aplikací), návštěva rodiny či kamarádů, oslava a randění. Touto aktivitou průměrně stráví respondenti okolo hodiny denně. Dívky tráví komunikací o třetinu času denně více než chlapci. Již od raného dětství komunikují matky více s dcerami než se syny a dotvářejí představu získanou naším kulturním prostředím, v němž dívky a ženy mluví více než chlapci a muži. Přesto rozdíl ve verbálních schopnostech není tak zřejmý, jak se často předpokládá; největší rozdíly se objevují v prvních třídách základních škol, v pozdějších letech jsou rozdíly ve výkonech minimální (Janošová, 2008). Přesto v testu verbální tvořivosti chlapci skórovali významně hưr̆ než dívky.

Žáci ze základních škol komunikují s druhými ve svém volném čase častěji než studenti gymnázií, přesto dosahují slabších výsledků v testech tvořivosti než studenti gymnázií. Zdá se tedy, že nezáleží na množství, ale na kvalitě verbálních projevů, což podporuje např. teorie jazykových kódů Bernsteina (1971), v níž jde o pregnanci a bohatost popisu před množstvím slovní databáze.

Aktivity tvořivé jsou činnosti, při kterých jedinec vytváří něco originálního, vynalézavého a inovativního. Mezi ně byly zařazeny aktivity manuálně tvořivé jako oprava auta, tvorba z korálků, modelářství, výtvarné činnosti, fotografování a úprava fotografií, tvorba webových stránek, módní návrhářství a tvorba účesů, hra na hudební nástroj, programování, psaní deníků a příběhů, blogování, četba knih, vypracovávání úkolů a přemýšlení. V př́padě tvořivých zájmů a faktorů tvořivosti byly nalezeny vztahy, které jasně potvrzují uvedený předpoklad, a to i přes zjištění, že touto činností průměrně tráví respondenti nejméně času, okolo hodiny denně. Je tedy jasné, že pokud jedinec provozuje častěji tvořivé aktivity, vykazuje lepší výsledky v tvořivostních testech. Je ale otázkou, jestli tvořiví jedinci vyhledávají častěji tvořivé aktivity, nebo jestli tvořivé aktivity rozvíjejí tvořivý potenciál.

Také bylo sledováno, zda existuje vztah mezi tvořivostí, genderem a typem školy. Ukázalo se, že dívky dosahovaly lepších výsledků v testech tvořivosti než chlapci. Tento nález koresponduje s výsledky naší původní studie (Zvěřinová, Janošová, 2012). Dívky tráví méně času pasivními zájmy. Zdá se, že v jejich př́ípadě hraje určitou roli rozmanitější skladba volnočasových aktivit, možná i to, že tráví nutnými úkony o hodinu denně více času než chlapci. Možná jsou dívky oproti chlapcům k tvořivosti i více vedeny výchovou (srov. Janošová, 2008).

Studenti gymnázií dosahují lepších výsledků v testech tvořivosti než žáci základních škol. Ukazuje se, že typ školy je z hlediska tvořivosti důležitý. Povaha zjištěných dat však neumožňuje určit prŕíčinu tohoto rozdílu. Výsledky naznačují, že u studentů gymnázií nehraje typ volnočasové aktivity $\mathrm{z}$ hlediska jejich výkonu v tvořivosti významnou roli, jako je tomu u žáků základních škol. Přestože výzkumy nepotvrdily vztah mezi tvořivostí a inteligencí u dospělých (např. Preckel et al., 2006; Kim, 2004), zde se tato souvislost velmi tentativně nabízí. Je možné, že děti s určitým kognitivním profilem a nadáním mají specifický tvořivý výkon a zároveň si volí tvořivé aktivity. Teoreticky může být vztah mezi inteligencí a tvořivostí také zprostředkovaný, resp. moderovaný dalším faktorem, např́klad podnětným rodinným 
prostředím, podporujícím u dětí školní výkon i rozmanitější (tvořivější) zájmy. Gymnázium může být zároveň podnětnějším prostředím pro rozvoj verbálních dovedností, může však žáky také lépe připravovat v tom, jak funkčně vyplňovat podobné písemné úkoly. A možné je i to, že je gymnázium pro rozvoj tvořivosti podnětnějším prostředím než základní škola. Bohužel ani jedno z nastíněných odůvodnění nelze v této studii potvrdit ani vyvrátit.

\section{Závěr}

Porozumět tomu, kde se v jedinci bere tvořivost, je velice obtížné. Tato studie si kladla za cíl přispět k pochopení souvislostí mezi verbální a neverbální tvořivostí a volnočasovými aktivitami u nynější populace adolescentů. Zkoumání volnočasových zájmů dětí a adolescentů je jednou z cest, jak uchopit a porozumět specifikům tvořivosti u této sledované skupiny.

Výsledky této studie poukazují na tři základní vztahy mezi 1) tvořivými volnočasovými aktivitami a tvořivostí, 2) záporným vztahem mezi pasivními zájmy a tvořivostí a 3) pozitivním vztahem mezi sociálními zájmy a verbální tvořivostí.

Vybírá-li si však tvořivý jedinec tvořivý zájem nebo opačně, zda tedy tvořivý zájem rozvíjí běžného jedince, nelze určit. Stejně tak není možné odpovědět, jestli pasivní zájmy vytvářejí deficit v oblasti tvořivého myšlení, nebo jestli si pasivní zájmy preferují jedinci netvořiví. Nabízí se také možné vysvětlení, že jedinci disponovaní k tvořivosti preferují tvořivé zájmy, které tuto jejich kognitivní schopnost dále rozvíjejí. Ověřit tento předpoklad průřrezovým metodologickým přístupem není možné. To je také jeden z hlavních limitů této výzkumné studie.

Omezením této studie je sledování výkonu v tvořivosti operacionalizované pouze ve dvou z jejích mnoha možných komponent - tvořivost neverbální (výtvarně tematická, figurální) a verbální. Pokud by byla zkoumána tvořivost např́iklad v oblasti pohybové nebo hudební, možná by byly zachyceny zcela odlišné výkony a také jiné vztahy se sledovanými volnočasovými zálibami. Také zvolený způsob operacionalizace na figurální a verbální komponenty tvořivosti je jen jedním z mnoha možných. Dalším omezením této studie je způsob členění zjištěných aktivit do zvolené typologie. Analýza sledovaných vztahů u jednotlivých zájmů nebo jejich odlišná kategorizace by mohla vést k jiným závěrům. Závěry této studie je tedy nutné zvažovat s ohledem na tato její specifika.

Povaha nálezů přes veškerá omezení umožnila ověřit stanovené předpoklady. Výsledky studie, jak doufáme, přinášejí i určité podněty pro další výzkum tvořivosti a volnočasových zájmů adolescentů. 


\section{Literatura}

Almeida, L. S., Prieto, L. P., Ferrando M., Oliveira E. \& Ferrández C. (2008). Torrance Test of Creative Thinking: The question of its construct validity. Thinking Skills and Creativity, 3, 53-58. http://doi.org/10.1016/j.tsc.2008.03.003

Amabile, T. (2018). Creativity and Labor of Love. In R. J. Sternberg, \& J. C. Kaufmann (Eds.), The Nature of Human Creativity. pp. 1-15. Cambridge University Press.

Baer, J. \& Kaufman, J. C. (2005). Bridging generality and specifity: The Amusement Park Theoretical (APT) model of creativity. Roeper Review, 27, 158-163. http://doi.org/10.1080/02783190509554310

Beghetto, R. A. (2014). Creative mortification: An initial exploration. Psychology of Aesthetics, Creativity, and the Arts, 8(3), 266-276. http://doi.org/10.1037/a0036618

Beghetto, R. A. (2018). Do We Choose Our Scholarly Paths or Do They Choose Us? My Reflection on Exploring the Nature of Creativity in Educational Settings. In R. J. Sternberg, \& J. C. Kaufmann (Eds.), The Nature of Human Creativity. pp. 32-46. Cambridge University Press.

Beghetto, R. A. \& Kaufman, J. C. (2007). Toward a broader conception of creativity: A case for "mini-c" creativity. Psychology of Aesthetics, Creativity, and the Arts, 1(2), 73-79.

https://doi.org/10.1037/1931-3896.1.2.73

Beghetto, R. A. \& Kaufman, J. C. (2009). Beyond big and little: The Four C Model of Creativity. Review of General Psychology, 13, 1-12. http://doi.org/10.1037/a0013688

Bernstein, B. (1971). Class, Codes and Control. Volume 1: Theoretical Studies Towards a Sociology of Language. London and Boston: Routledge and Kegan Paul.

Bucksch, J., Inchley, J., Hamrik, Z., Finne, E. \& Kolip, P. (2014). Trends in television time, non-gaming PC use and moderate-to-vigorour physical activity among German adolescents 2002-2010. BMC Public Health. http://doi.org/10.1186/1471-2458-14-351

Cramond, B., Matthews-Morgan, J., Bandalos, D. \& Zuo, L. (2005). A report on the $40-$ year follow-up of Torrance Tests of creative thinking: Alive and well in the new millennium. Gifted Child Quarterly, 49(4), 283-291. http://doi.org/10.1177/001698620504900402

Cropley, A. (2018). Bringing Creativity down to Earth A Long Labor Lost? In R. J. Sternberg, \& J. C. Kaufmann (Eds.), Nature of Human Creativity. pp. 47-62. Cambridge University Press.

Csikszentmihalyi, M. (1996). Creativity: Flow and the Psychology of Discovery and Invention. New York: Harper Perennial.

Dacey, J. S. \& Lennon, K. H. (2000). Kreativita. Praha: Grada.

Gardner, H. (1999). Dimenze myšlení: teorie rozmanitých inteligencí. Praha: Portál.

Feist, G. J. (2010). The Function of Personality in Creativity. In J. Kaufman \& R. Sternberg (Eds.), The Cambridge Handbook of Creativity. pp. 113-130. Cambridge: Cambridge University Press. https://doi.org/10.1017/CBO9780511763205.009

Hamlen, K. R. (2009). Relationships between computer and video game play and creativity among upper elementary school students. Journal of Educational Computing Research, 40(1), 1-21. https://doi.org/10.2190/EC.40.1.a

Hennesey, B. A. (2018). I never Intended to Become a Research Psychologist. In R. J. Sternberg, \& J. C. Kaufmann (Eds.), The Nature of Human Creativity. pp. 110-124. Cambridge University Press.

Hlavsa, J. \& Jurčová M. (1978). Psychologické metódy zistovania tvorivosti. Bratislava: Psychodiagnostické a didaktické testy.

Hlavsa, J. (1981). Psychologické problémy výchovy k tvořivosti. Praha: SPN. 
Chalupa, B. (2005). Tvořivé myšlení, Tvořivost jako dobrodružství poznání. Brno: Barrister \& Principal.

Janošová, P. (2008). Dívči a chlapecká identita, vývoj a úskalí. Praha: Grada.

Jurčová, M. (1984). Torranceho figurálny test tvorivého myšlenia. Bratislava:

Psychodiagnostické a didaktické testy.

Kant, R. (2012). Television and creativity. Online International Interdisciplinary Research Journal, 2, 3. http://www.oiirj.org/oiirj/may-june2012/05.pdf

Kim K. H. (2006). Can we trust creativity tests? A review of the Torrance Tests of Creative Thinking (TTCT). Creativity Research Journal, 18 (1), 3-14. https://doi.org/10.1207/s15326934crj1801_2

Kim, K. H. (2004). „Can only intelligent people be creative?" Journal of Secondary Gifted Education, 16, 57-66. https://doi.org/10.4219/jsge-2005-473

Kirkorian, H. L., Wartella, E. \& A. Anderson, D. R. (2008). Media and young children are leasing. Future of Children, 18(1), 39-61. https://doi.org/10.1353/foc.0.0002

Königová, M. (2006). Jak myslet kreativně. Praha: Grada.

Kraus, B., Poláčková, V. \& kol. (2001). Člověk-prostředí-výchova. Brno: Paido.

Krumm, G., Lemos, V. \& Richaud, M. C. (2018). Personality and creativity: A study in Spanish-speaking children. International Journal of Psychological Research, 11(1), 33-41. https://doi.org/10.21500/20112084.2867

Larson, R. W. (2001). How U.S children and adolescents spend time: What it does (and doesn't) tell us about their development. Current Directions in Psychological Science, 10(5), 160-164. https://doi.org/10.1111/1467-8721.00139

Lucas, B. (2016). A five-dimensional model of creativity and its assessment in schools. Applied Measurement in Education, 29(4), 278-290. https://doi.org/10.1080/08957347.2016.1209206.

Mareque, M., de Prada Creo, E., \& Gonzalez-Sanchez, M. (2019), Fostering creativity and communicative soft skills through leisure activities in management studies. Education + Training, 61(1), 94-107. https://doi.org/10.1108/ET-07-2018-0149

MŠMT (2015). Strategie vzdělávací politik do roku 2020. http://www.vzdelavani2020.cz/images_obsah/dokumenty/strategie/dz-rgs-2015-2020.pdf

Pávková, J., Hájek B., Hofbauer B., Hrdličková V., \& Pavlíková A. (2008). Pedagogika volného času. Praha: Portál.

Petrová, A. (1999). Tvořivost v teorii a praxi. Praha: Vodnář.

Preckel, F., Holling, H., \& Wiese, M. (2006). Relationship of intelligence and creativity in gifted and non-gifted students: An investigation of threshold theory. Personality and Individual Difference, 40, 159-170. https://doi.org/10.1016/j.paid.2005.06.022.

Ripple, R. E. \& Dacey, J. (1967). The facilitation of problem solving and verbal creativity by exposure to programmed instruction. Psychology in the Schools, 4(3), 240-245.

Runco, M. A. (2014). Creativity. Theories and themes: Research, development, and practice. Elsevier.

Runco, M. A., Millar, G., Acar, S. \& Cramond, B. (2010). Torrance Tests of Creative Thinking as predictors of personal and public achievement: A fifty-year follow-up. Creativity Research Journal, 22(4), 361-368. https://doi.org/10.1080/10400419.2010.523393

Runco, M. A., \& Pezdek, K. (1984). The effect of television and radio on children's creativity. Human Communication Research, 11(1), 109-120. https://doi.org/10.1111/j.14682958.1984.tb00040.x 
Sak, P., \& Saková, K. (2004). Mládež na křižovatce: sociologická analýza postavení mládeže ve společnosti a její úlohy v procesech evropeizace a informatizace. Praha: Svoboda Servis.

Sak, P. (2000). Proměny české mládeže. Praha: Petrklíč.

Sak, P. (2016). Generace, mládež a její výzkum. Mládež a spoločnost, 22 (2),7-13.

Sternberg, R. J. (1988). The triarchic mind. New York: Viking.

Sternberg, R. J. \& Lubart T. I. (1991). An investment theory of creativity and its development. Human Development, 34(1), 1-31. https://doi.org/10.1159/000277029.

Szobiová, E. (2016). Tvořivost'-poznavanie tajomstiev. Plzeň: Aleš Čeněk.

Šafr, J. \& Patočková V. (2010). Trávení volného času v České republice ve srovnání s evropskými zeměmi. Naše společnost, 8(2), 21-27.

Torrance, E. P. (1966). The Torrance Tests of Creative Thinking-norms-technical manual Research Editionverbal tests. Forms A and B-figural tests, Forms A and B. Princeton: Personell Press.

Torrance E. P. (1991). The Nature of Creativity as Manifested in its Testing. In R. J. Sternberg (Ed.), The Nature of Creativity. 76-98. New York: Cambridge University Press.

Vleioras, G. (2010). Time use Hellene 3rd and 4th grades during a school day. European Journal of Developmental Psychology, 7(4), 463-478. https://doi.org/10.1080/17405620802613893.

Wade, S. E. (1971). Adolescence, creativity and media. American Behavioral Scientist,14, 341-351.

Zelina, M. \& Jaššová, E. (1984). Tvorivost' - piata dimenzia. Bratislava: Smena.

Zvěřinová, J. \& Janošová, P. (2012). Hraní počítačových her u adolescentů ve vztahu k jejich tvořivosti. Psychológia a patopsychológia dietata, 46(2), 95-112.

Žák, P. (2004). Kreativita a její rozvoj. Brno: Computer Press.

\section{Informace o autorce}

Mgr. Jana Poddaná (dřive Zvěřinová) je postgraduální studentkou pedagogické psychologie na Jihočeské univerzitě v Českých Budějovicích. Výzkumně se zaměřuje na tvořivost dětí a adolescentů ve vztahu k volnočasovým aktivitám. Profesně vyučuje psychologii a projektové vyučování na střední škole, kde se u svých studentů snaží rozvíjet tvořivý potenciál.

\section{Kontaktní údaje}

Adresa: Kubíkova 1180, Praha 8

Email: zverij00@pf.jcu.cz

Poddaná, J. (2020). Vztah preferovaných volnočasových aktivit a tvořivosti u českých adolescentů. E-psychologie, 14(3), 1-16. https://doi.org/10.29364/epsy.375 